\title{
$\AA$ ta
}

seg selv

alvorlig

\author{
Noen har introdusert begrepet «det nye alvoret» om den livsanskuelsen hun formidler. \\ Ironisk distanse er avløst av en ny bølge preget av inderlighet, åndelighet og søken etter \\ mening. Legeforeningen har fått en president som er mer opptatt av hva verden kan \\ bruke henne til enn omvendt.
}

Å la seg portrettintervjue er ikke uten en viss risiko. Man utsetter seg for den andres blikk og gir fra seg kontrollen over alt annet enn direkte sitater og faktafeil. Jeg har forberedt meg på at Hege Gjessing, fortsatt relativt ny som leder av en av landets mektigste fagforeninger, vil møte meg vennlig, profesjonelt og antakelig litt upersonlig selvbeskyttende, slik maktmennesker gjerne gjør. De kan spillet og vet hvordan de skal regissere seg, har jeg tenkt. Etter at det hele er over, to intense timer senere, sitter jeg tilbake nesten beskjemmet, men først og fremst berørt av den tilliten hun har vist meg.

- Jeg stoler på deg, sier hun når hun går.

Tilbake til start og et forsøksvis skjermet hjørnebord et sted der de serverer grei og ujålete mat. Jeg hadde fått tips om å intervjue henne i en kaffebar - «Hege er ekstremt glad i kaffe» - men har ønsket meg en samtale over et måltid. Det skjer noe når mennesker spiser sammen. Hege Gjessing vil ha steinbit og grønn te. Jeg synes det er en veldig rar kombinasjon. Hun ler litt og forklarer at hun er blitt forkjølet og dessuten har oppdaget at grønn te gjør henne godt. - Men det er ingen som liker grønn te? Er ikke det bare for å dekke over at man er litt sånn sunnhetsjunkie?

- Nei, jeg liker det faktisk. Men den må lages riktig. Vannet må ikke være for varmt, og så er det veldig viktig at den ikke trekker for lenge. Mitt problem var at jeg ble, eller er, helt avhengig av kaffe og drakk så mye at jeg ble skjelven. Fortsatt går det mye $i$ kaffe, men etter at jeg innførte grønn te i livet mitt, har jeg fått det bedre. Man får rett og slett en følelse av å bli ren. Det er vanskelig å beskrive.

Her iler kelneren, en danske som kan sin grønne te, entusiastisk til og forteller at det er 68 grader og tre minutter som gjelder.

Hege Gjessing har høflig sendt e-post med beskjed om at hun blir noen minutter forsinket. Dertil er hun altså forkjølet og sikkert også sliten etter en lang dag på Gardermoen med diskusjoner om informasjonsteknologi i helsesektoren. Dit kom hun rett fra jubileumsfeiring i Nordland legeforening i Bodø dagen før.

- Representasjonsoppgavene er en viktig del av jobben, og det er stas å være ønsket til lokale arrangementer. Samtidig er disse reisene en personlig bonus for meg. Jeg har

\section{«Jeg har stor respekt for ledelse, men ikke for autoritet for autori- tetens skyld»}

flyttet mye rundt - Harstad, Drammen, Bergen, Trondheim, Sandnessjøen, Stokmarknes - og er utrolig glad i Norge.

Her hun sitter rett overfor meg, lenge etter at folk flest har gått hjem fra jobb, er det ikke synlige spor av slitenhet i smilet vi kjenner godt fra de offentlige bildene av henne. Ja, hun har et vakkert ansikt med et ekte smil. Og noen forsiktige rynker. Vi kan godt begynne med dem.

\section{Ung kvinne?}

Det er vanskelig å komme utenom at mange både $\mathrm{i}$ og utenfor Legeforeningen vil mene at presidenten kommer i kategorien «ung kvinne», med alle de assosiasjoner det gir. Både «ung» og «kvinne» kan brukes for å heie frem eller devaluere, avhengig av motiv og øynene som ser.

Hege Gjessing fylte 40 år i mars.

- Jeg synes ikke jeg er ung lenger. Ikke vil jeg være det heller. Det er deilig å ha nådd dit $\mathrm{i}$ livet at jeg føler meg trygg på at jeg har mye å bidra med, kjenne at jeg har lyst til å være voksen og ta ansvar. Da jeg var leder i Yngre legers forening, tenkte jeg en del på hvordan «ung lege» iblant ble brukt som hersketeknikk, for å holde kolleger nede eller kanskje beskytte seg mot den nye kunnskapen de brakte med seg. Jeg begynte på sykehus etter noen år i allmennmedisinen, der man jobber mer alene og både får $\mathrm{og}$ tar mer direkte personlig ansvar. Å oppleve at en erfaren anestesilege i 50 -årene fortsatt omtalte seg selv som ung overlege var en tankevekker.

En moderne leder er naturligvis dreven i omgang med sosiale medier. Hege Gjessing og jeg «følger hverandre», som det heter på twitterspråket. I august la jeg merke til at hun videreformidlet en artikkel fra det amerikanske damebladet Vogue der budskapet var bekymring over botoxinjeksjoner, som snart er like vanlig som å gå til frisøren. «Ja til naturlig, vakker aldring» var konklusjonen.

- Det med kirurgisk forskjønning opptar meg. Hele konseptet spiller på usikkerhet, at vi ikke er bra nok som vi er. Selv blir jeg veldig forstyrret når noen ikke er naturlige i ansiktet. Man ser jo at noe er feil selv om det liksom skal være pent. Det er vanskelig å forstå at botoxbruk skal bidra til kvinnefrigjøring, slik enkelte hevder. Når et profilert dameblad som Vogue stiller seg så kritisk, er det grunn til å håpe at de målbærer en ny trend der skjønnhet blir definert videre. Jeg synes vi skal feire alle aldre.

Det skåles i henholdsvis grønn te og lettøl ved hjørnebordet. Rundt oss i restauranten sitter det etter hvert et skravlende, leende og spisende mangfold av noen menn og veldig mange damer $i$ alle aldre. Ja, det er antakelig viktig at Legeforeningens president freidig kringkaster sine synspunkter på skjønnhetsindustrien.

\section{Å bli valgt}

De som lurer på hva Hege Gjessing mener om helsepolitiske saker eller vil ha detaljer 


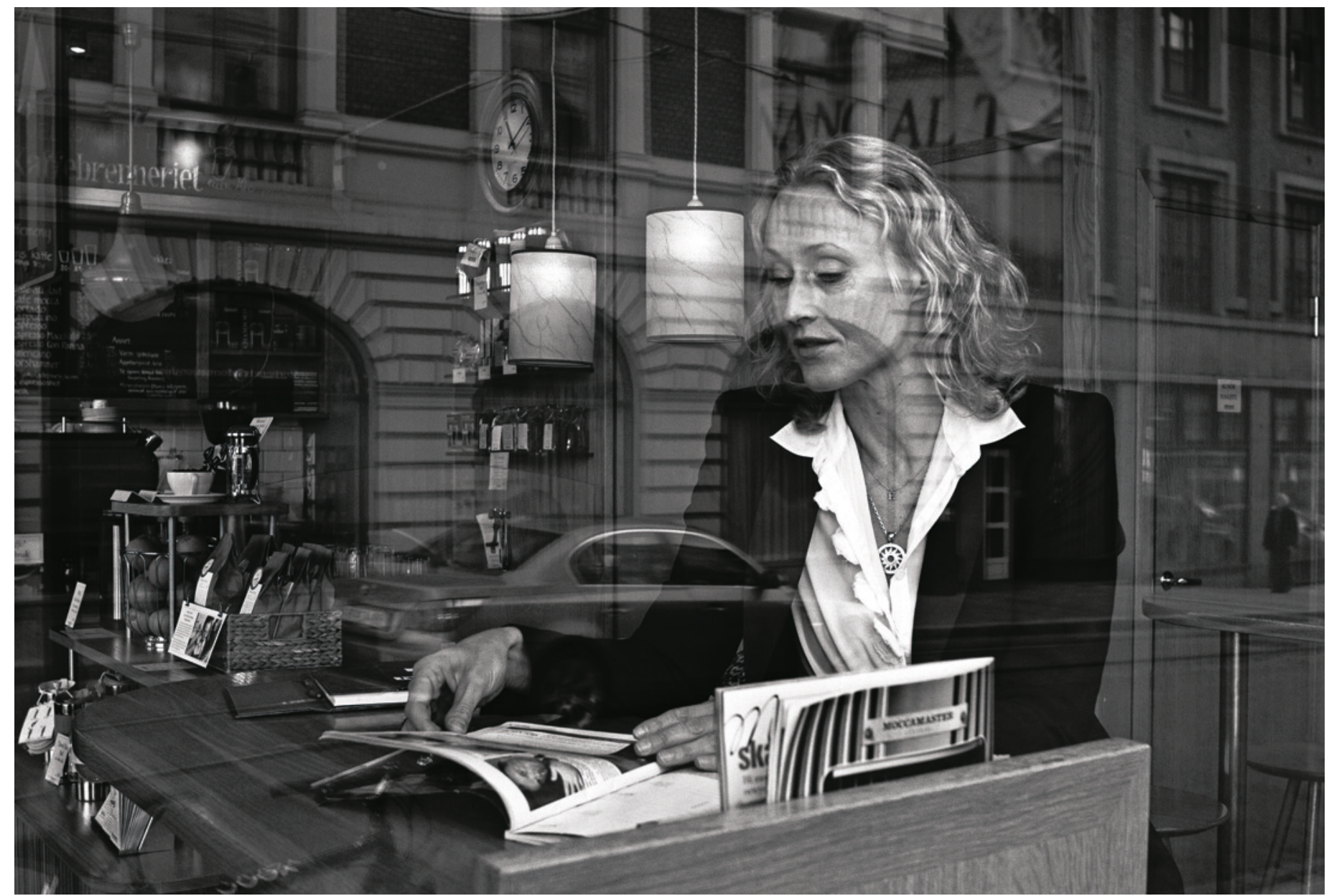

Foto Einar Nilsen

\section{Hege Gjessing}

Født 1972

- Cand.med. Universitetet i Bergen 1998

- Kommunelege i Lurøy og fastlegevikar i Oslo 2000-03

- Oppdrag for Leger uten grenser i Sudan 2002

- Lege i spesialisering, anestesi, Akershus universitetssykehus og Rikshospitalet, 2003-07

- Leder Yngre legers forening 2007-11

- President Den norske legeforening fra 2011 fra hennes profesjonelle karriere, vil med noen få tastetrykk finne det de leter etter. Selv er jeg alltid mer nysgjerrig på «hvorfor» enn «hva» og «hvordan». Hun stakk seg ikke frem som barn, var ingen politisk barrikadekjemper, hadde aldri tenkt på seg selv som leder og i alle fall ikke for en fagforening før en kollega satte henne på det sporet. Hun startet sin nåværende karriere som foretakstillitsvalgt på Akershus universitetssykehus.

- Jeg var helt uinteressert og kunne ingenting om fagforeningsarbeid. Mitt forhold til lønnskamp var å registrere at beløpet på lønnsslippen stemte sånn omtrent. Derimot har jeg nok alltid hatt en sterk rettferdighetssans. Kollegaen som overtalte meg til å stille som foretakstillitsvalgt, kom med forslaget etter å ha sett meg i en konkret situasjon, en konflikt med en overordnet som mange var ganske redde for. Jeg syntes også situasjonen var ubehagelig, men jeg visste at jeg hadde rett og måtte virkelig tenke over om jeg var villig til å inngå et uverdig kompromiss for å tilpasse meg det som vel kan kalles en ukultur. Det hele endte faktisk med at min mot- part fremførte det nærmeste han kunne komme et unnskyld. Jeg har stor respekt for ledelse, men ikke for autoritet for autoritetens skyld.

- Så du har ikke bevisst søkt makt?

- Jeg opplever det ikke slik. I det hele tatt tror jeg mer på at man blir valgt enn at man velger. Veldig mange, særlig unge $\mathrm{i}$ vårt samfunn, spør seg selv hele tiden om hva de har aller mest lyst til. Det er så mange valg og så mye å gå glipp av. Jeg tror det er mer fruktbart å stille spørsmålet omvendt. Hvordan kan jeg bruke kreftene mine riktig? Hva egner jeg meg til? Hvor kan jeg gjøre best nytte for meg?

Jeg kaster inn begrepet «kallstanke». Hun avviser det ikke, selv om hun nødig vil fremstå som pompøs.

- For meg er veien blitt til mens jeg har gått, ikke særlig målrettet. Svarene har kommet til meg, sier hun.

\section{Oppdraget}

- Med utgangspunkt i det ganske strenge påbudet du gir deg selv, altså om å være til nytte og gjøre det rette: Er oppdraget som Legeforeningens president deg verdig? 
Får du gjort det nyttige og det rette fra den posisjonen?

- Ja, nå føler jeg det slik. Legeforeningen har stor innflytelse i kraft av at vi er faglig gode og har mange å spille på. Så lenge vi klarer å vise at vår hovedintensjon er bidra til så gode helsetjenester som mulig, og så lenge vi har gode argumenter og er klare og tydelige, blir vi også lyttet til. Jeg er opptatt av at legene skal gjøre seg gjeldende som premissleverandører, at vi skal ha selvtillit og faglig glød. Det bekymrer meg at mange kolleger er så slitne og opplever det som nesten umulig å få gjort jobben sin slik de mener den bør gjøres.

Jeg minner henne på jubileumsintervjuet jeg gjorde med de gjenlevende ekspresidentene da Legeforeningen fylte 125 år. Fra de distingverte herrene ble det mer enn antydet at den nye generasjonen leger tåler mindre og er langt mer kravstore enn sine forgjengere. Hege Gjessing tror det ligger andre mekanismer bak.

- Det er særlig i sykehusene vi ser at legene blir proletarisert, om man kan bruke det begrepet. Liggetiden går ned, pasientene er sykere, stadig flere av dem har livsstilssykdommer som det er vanskelig å gjøre noe med. Forventningene øker parallelt med avmakten.

- Og Legeforeningens botemiddel?

- Vi må bidra til god ledelse på alle nivåer og utvikle et kollegium som er raust og mangfoldig. Målet må være at høyt utdannede fagfolk, som leger jo er, får anledning til å gjøre det de er flinkest til under betingelser som egner seg for formålet.

- Hva med incentivstrukturene? Du snakker jo akkurat nå med en som ikke tror på stykkprisfinansiering i helsevesenet ...

- Det vil alltid være en balansegang mellom forutsigbarhet og frihet. Jeg synes det er bra om vi som yrkesgruppe selv kan gå inn og reflektere åpent over hva incentivstrukturene gjør med oss, på gruppenivå og som individer.

- Er du redd for åpen uenighet mellom kolleger? Skal vi som ytrer oss være forsiktige av hensyn til lauget?

- Tvert imot. Jeg skulle ønske leger tok større plass i den offentlige samtalen, ikke minst når det gjelder faglige spørsmål. Det er klart at man som forening i gitte situasjoner har behov for å tale med én stemme. Selv er jeg imidlertid bevisst på å bruke ordet «kamp» så lite som mulig. Noen er kritiske til en slik holdning, men jeg vil at åpenhet og dialog skal være vår metode. Jeg tror også at legenes omdømme står seg på ikke å krisemaksimere og ty til krigsretorikk i utide.

\section{Livets regnestykker}

Hege Gjessing har altså ikke søkt makt for maktens egen skyld. Likevel er det et faktum at hun har forvaltet seg slik at hun nå tilhører en maktelite. Da er det også interessant, kanskje særlig i et kvinneperspektiv, å spørre hva det koster. Svaret kan antakelig oppsummeres i det hun sa på slutten av en ganske lang dialog om livet og Livet. Én liten setning som gjorde et betydelig inntrykk på intervjueren: «Jeg har ikke for vane å savne.»

Nei, hun er ikke en prinsipielt enslig dame med et angstbitersk, resignert forhold til familie. Hun deler sjenerøst av erfaringer og håp. Hun tør snakke om det hun kaller «ufrivillig alenetid», om gjenkjennelige

\section{«Jeg skulle ønske leger tok større plass i den offentlige samtalen»}

angster, tap og sorg. Hun tør til og med si med vanlig stemme at hun tror på den store kjærligheten og håper at den skal bli henne til del. Hvis hun tør, som hun sier. Hun tør til og med si at hun nok ikke er blant kvinnene med mest uttalt ønske om barn. Idet hun har sagt det med barn, skynder hun seg å legge til, obligatorisk, nesten unnskyldende: «Men jeg er veldig glad i barn, altså.» Vi ler litt sammen av den kulturelle for-sikkerhets-skyld-refleksen. Fortsatt brennes nok hekser på bål, selv om det skjer i dannede former.

Mest snakker hun likevel om å arbeide med seg selv.

- Jeg hadde aldri vært der jeg er nå hvis jeg ikke hadde greid å finne troen på meg selv og dessuten tatt i bruk de mulighetene som det faktisk gir å være enslig. Det er klart jeg beveger meg annerledes i livet enn en småbarnsmor.

Hun har forutsetninger for å uttale seg. Hennes mor var alene med tre små barn da
Hege Gjessing var liten. Måtehold og hardt arbeid var ikke dyder som ble prediket i pedagogisk øyemed, de var nødvendige for å få endene til å møtes. Moren, som var sykepleier, var opptatt av at barna skulle få god utdanning.

- Mamma sa at jeg heller burde bli lege enn sykepleier. Da ville jeg få større inn-

flytelse.

- Er moren din stolt av deg?

- Ja, og jeg er stolt av henne.

\section{Mening og mestring}

Dette tvitret hun 24. september 2012:

«Meatfree monday - pluss forebygging i form av joggetur (man må leve som man lærer).» Jeg begynner å forstå mer av hvordan hun investerer i seg selv som ressurs. Hun har fortalt meg at hun er med i en løpegruppe, helst fire kvelder i uken hvis hun får det til. I fjor sprang hun helmaraton på under fire timer. - En fin måte å se København på, som hun sier. Hun er opptatt av kosthold og bekymret over nasjonens forbruk av sukker og hvitt mel. I sommer var hun på meditasjonskurs i Sverige.

- Det høres deilig..

- Det var ti timer hardt arbeid hver dag i ti dager. Metoden heter Vipassana, som betyr å se med åpne øyne. Man sitter helt stille, i stillhet, med blikket vendt innover. I begynnelsen var jeg stolt over å klare det, så kom smerten. Det fascinerende er å oppleve hvordan smerte - både fysisk og mentalt - slipper gjennom å holde ut. Det er som en renselse.

Måltidet er over. Hege Gjessing må være sliten. Jeg unner henne på en måte at hun skal kjenne seg sliten. Moren hennes er bare noen år eldre enn meg. Kanskje er det noe sånt som slår inn og får meg til å holde henne igjen med et siste spørsmål idet hun reiser seg for å gå. Løpe, for alt jeg vet. - Du. Hva gjør du når du trenger hvile?

- Jeg bruker musikk i mange situasjoner. Nylig oppdaget jeg en rapper som heter Nico D. Han gjør meg glad. Når jeg trenger energi setter jeg på Mary Jane Blige. Hvile finner jeg på denne tiden av året, når det begynner å bli høst og mørkt, aller mest i ulike versjoner av Stabat mater.

Elisabeth Swensen

elswense@online.no

Tidsskriftet 